\title{
微粒子ピーニングによる加工熱処理と金属間化合物層の創成
}

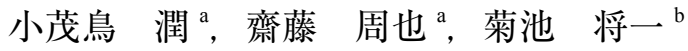 \\ a 慶應義塾大学 理工学部 ( ⿳ 223-8522 神奈川県横浜市港北区日吉 3-14-1) \\ $\mathrm{b}$ 神戸大学 大学院工学研究科 ( $=657-8501$ 兵庫県神戸市灘区六甲台町 1-1)
}

\section{Development of a New Surface Modification Process by Fine Particle Peening}

\section{Jun KOMOTORI ${ }^{\text {, }}$, Shuya SAITO ${ }^{\text {a }}$ and Shoichi KIKUCHI ${ }^{\text {b }}$}

\author{
${ }^{a}$ Faculty of Science and Technology, Keio University(3-14-1, Hiyoshi, Kohoku-ku, Yokohama-shi, Kanagawa 223-8522) \\ ${ }^{\mathrm{b}}$ Graduate School of Engineering, Kobe University(1-1, Rokkodai-cho, Nada-ku, Kobe-shi, Hyogo 657-8501)
}

Keywords : Surface Modification, Fine Particle Peening, Intermetallic Compound, Induction Heating

\section{1.はじめに}

微小な粒子を高速で被処理部材に投射する微粒子ピーニン グ(Fine Particle Peening：FPP)は, 国内で開発された技術で あり，様々な工業分野ですでに実用化されている。本誌(表 面技術)においても，2001 年に「ショットピーニング法によ る表面改質技術」 ${ }^{1)}$ という特集が企画され，そこでは，「最 近のショットピーニング」というタイトルで, この FPP 処 理が紹介されている。WPC処理 ${ }^{(\mathrm{R})}$ やFPB (Fine Particle Bombarding) 処理と呼ばれることもあるが, これらは全て同 一の処理を指している。

FPP 処理の効果に関しては，これまでに多くの興味深い報 告がある。例えば，大気中で金属チタン粉末を用いた FPP をチタン合金やアルミナ基材に施すと, その表面には酸化チ タン膜が形成されその結果として光触媒効果が発現すること ${ }^{2)}$ や，鋼に代表される金属に，硬質粒子を用いた FPP 処理を 施すと, 被処理面の結晶粒径が著しく微細なものになること

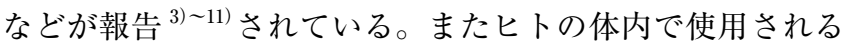
材料への応用も検討されており，FPPにより形成された凹凸 の効果により, 細胞の増殖性が向上すること ${ }^{12), 13)}$ が明らか になっている。

高速で微粒子が金属表面に投射されると，その部位は局所 的に加熱され，それにより熱処理効果が発現したり，投射粒 子成分が浸透拡散するということも言われている。著者らは とくにこの拡散に注目して，被処理材を加熱した状態で微粒 子投射が可能となる装置を最近開発し，それを用いた表面改 質技術の確立を目指した研究 ${ }^{14) ~ 26)}$ を行っている。本報では, その一部を紹介することとする。

\section{2. 雰囲気制御高周波誘導加熱微粒子ピーニングシス テム}

図 1 は AIH-FPP (Atmospheric controlled Induction-Heating Fine Particle Peening) システムの構成概念図である。真空チャ

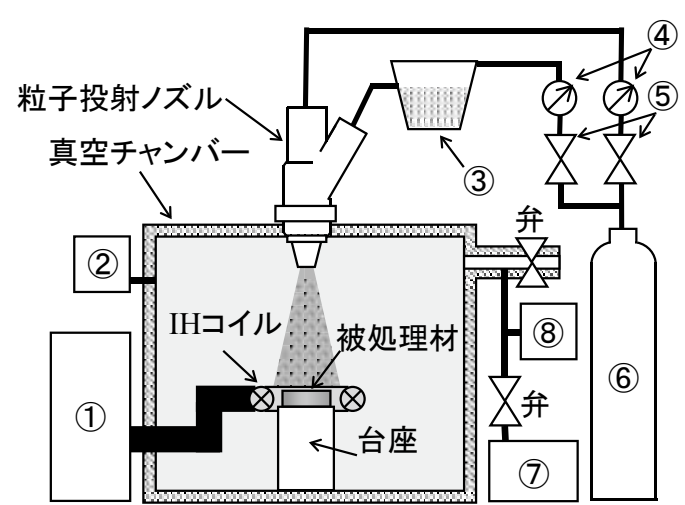

図 1 真空置換型 AIH-FPP 処理システムの模式図 (1) IH 電源装置, (2)真空計, (3)パーツフィー ダー, (4)流量計, (5)ガス噴射圧調整弁, (6)ガ スボンベ, (7)真空ポンプ, 8酸素濃度計)

ンバーの内部には, IH コイルと粒子投射ノズルが具備され ている。まず，チャンバー内を真空にした後，投射ノズルを 利用してアルゴンもしくは窒素などに䨌囲気を置換する。そ の状態で被処理材を IH により高温に加熱し微粒子を投射す ることができる。所望の性質を被処理面に付与するためには, 予め処理条件を詳細に検討する必要はあるが, IH コイルの 形状を工夫することにより, 丸棒や複雑形状の部品にも対応 可能であることや, 設備設計をすることによりインライン化 も可能になるものと考えている。

\section{3．AIH-FPP を利用した加工熱処理}

熱処理による鋼の結晶粒微細化は, 疲労特性をはじめ機械 的性質の向上に寄与するため古くから研究がされている。そ の中でも加工熱処理は, オーステナイト状態に加熱した鋼に 塑性変形を与えることで，これまでより微細な結晶を有する 鋼の実現が可能であり，部材の高強度化に寄与する技術とし て注目されている。しかしながら, 詳細な温度制御のもとで 
鋼に塑性変形を与えるためには大規模な装置の利用が必須と なり，このことが加工熱処理の幅広い実用化への妨げとなっ ている。

著者らは, 微粒子ピーニングが局所的には強加工をもたら すことに着目し，これを高温下で行うことにより，鋼の結晶 粒微細化を実現しようとする研究に取り組んでいる。具体的 には, 市販のクロムモリブデン鋼 (SCM435H) を供試材として, $400{ }^{\circ} \mathrm{C} \sim 700{ }^{\circ} \mathrm{C}$ に加熱した状態で，その表面に対して FPPを 施し, 結晶粒の微細化と疲労特性に及ぼす表面処理の効果を 調べた結果 ${ }^{18)}$ についてここでは紹介する

図 2 は表面処理の際の熱履歴である。試験片を一旦 $1000{ }^{\circ} \mathrm{C}$ まで加熱してオーステナイト組織とした後に圧縮気 体を噴射して所定の温度 $T_{1}$ まで急冷し, その温度を保持し た状態で粒子投射 (FPP)を 30 秒行っている。なおこの処理 のことを文献では, $\gamma$-FPP 処理と呼んでいる。図 3 は $\gamma$-FPP 処理により微細化した表面組織の光学顕微鏡写真である。同 図から明らかな通り, 表層近傍の深さ $20 \mu \mathrm{m}$ 程度の領域に は比較的微細な結晶粒が多く観察される。これは, ( i ) 微粒 子投射によりもたらされる高ひずみ速度の変形により，再結 晶の核が連続的に多数形成されること, (ii) 処理温度が比較 的低温の場合には, 再結晶粒の粗大化が抑制されることの両 者に起因するものと考えられている。

図 4 は $\gamma$-FPP 処理を施した SCM435H 鋼に対して，小野式 回転曲げ度労試験を行った結果である。図中, シリーズ名に

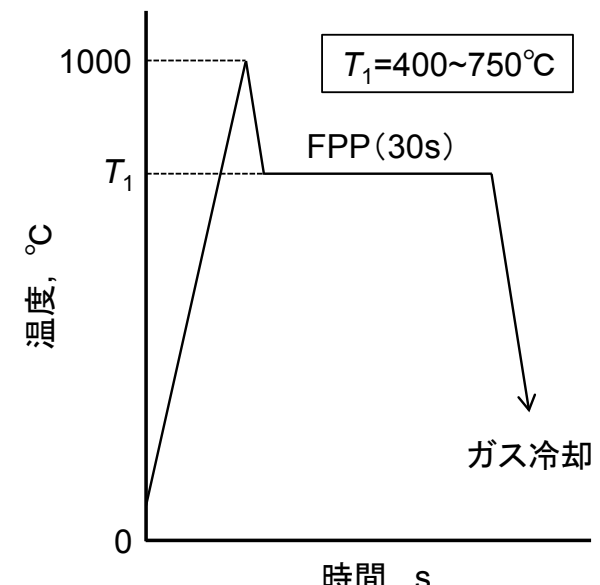

図 2 AIH-FPP 処理の熱履歴

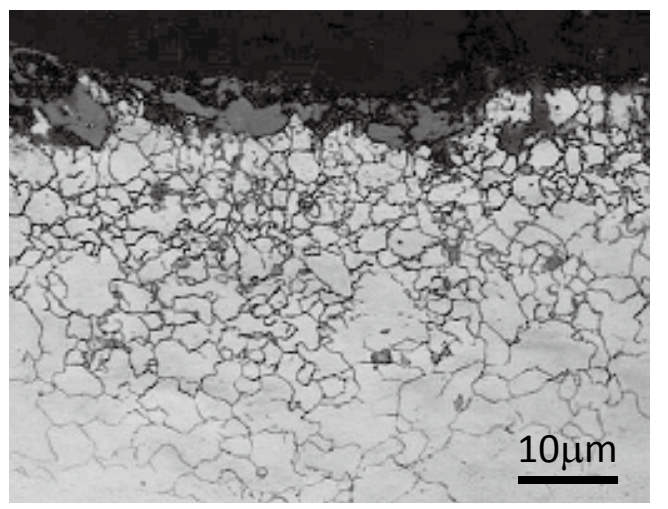

図 $3 \gamma$-FPP を施した試験片の表面近傍の結晶粒

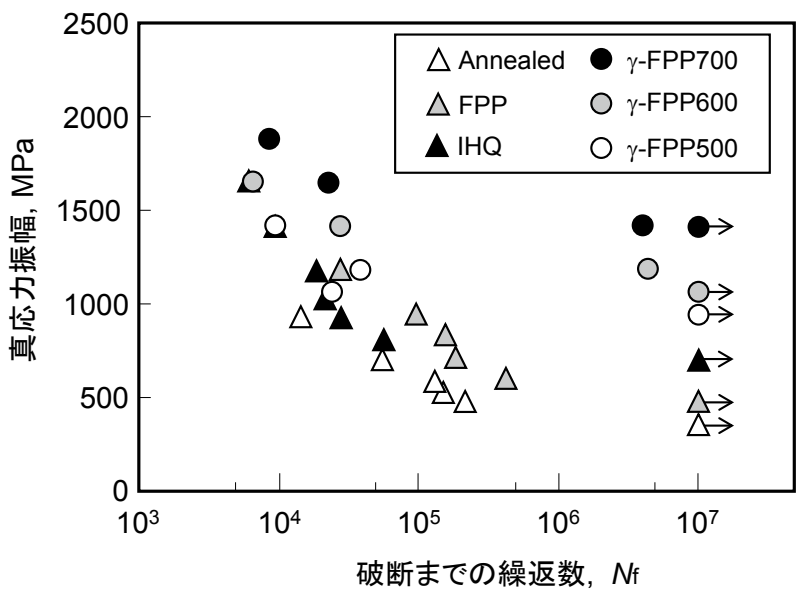

図 $4 \quad \gamma$-FPP を施した試験片の疲労特性

付した数字は, $\gamma$-FPP 処理の温度 $\left({ }^{\circ} \mathrm{C}\right)$ を示している。図中の $\triangle$ 印は比較材であり, Annealing を施した試験片の疲労試験 結果である。Annealed シリーズに室温大気中でFPPを施し た試験片の瘦労強度 $(\Delta)$ の上昇は僅かであるのに対して, $\gamma$ -FPP 処理を施した試験片の度労強度 $(\bigcirc, \bigcirc, \bigcirc)$ はいずれ も大幅に上昇していることがわかる。とくに, $700{ }^{\circ} \mathrm{C} て ゙$ 処理 を施した試験片の疲労強度は, 未処理の場合のおよそ 4 倍と なっている。この理由を検討するために, レプリカ法による 微小き裂の進展速度の比較を行っており, その結果, $700{ }^{\circ} \mathrm{C}$ で $\gamma$-FPP 処理を施した試験片の場合には, $300 \mu \mathrm{m}$ 以下の微 小き裂の進展速度が著しく低下することが明らかにされてい る。この温度で処理を施した場合には, FPPにより導入され る圧縮の残留応力はほとんど認められない。したがって, 図 4 に示されている疲労強度の上昇は, 処理による結晶粒微 細化が主要因と結論づけることができる。

熱処理や塑性変形により導入された圧縮の残留応力は, 種々の要因で開放されることがあるが, 結晶粒の微細化は比 較的安定と言える。処理システムも大規模なものが不要なこ とを考えると工業的には有効な処理となりうるものと考えて いる。

\section{4．AIH-FPP による金属間化合物層の創成}

金属間化合物は一般に, 耐熱性, 耐食性や耐摩耗性などに 優れるために，過酷な環境で使用される機械部品への応用が 産業界では期待されている。しかしながら，この金属間化合 物は加工が困難であり, バルク体をそのまま部品形状に仕上 げることは極めて難しい。そこで，予め形状創製した部材に

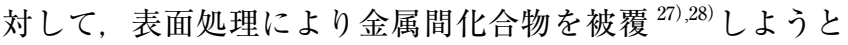
する試みが最近行われている。その手法の一つに，新しい溶 射法としてロシアで開発されたコールドスプレー法 ${ }^{29)}$ があ る。この方法は, $300 〜 1200 \mathrm{~m} / \mathrm{s}$ に加速された流れに 1 $50 \mu \mathrm{m}$ の粒子を投入して加速させ，固相状態のまま被処理材 に衝突させることにより被膜を形成する技術である。緻密で 比較的密着性の高い被膜を得ることが可能なことなど，様々 な長所はあるものの, 処理パラメータが多岐にわたることや それらの因子の相互作用も被膜の性質に影響を及ぼすため, 最適化が難しいということが指摘されている。 
最近，AIH-FPP を用いて金属間化合物被膜を創成しようと する試みが行われている。この場合は，投射粒子そのものは 常温であり投射速度も, 通常ショットピーニングよりは高速 であるが音速を超えるようなものではない。被処理材を予め 加熱することにより, 投射粒子同士，もしくは粒子と基材と の反応を加速しようとする点が大きな特徴と言える。

例えば図 5 は，IHにより $600{ }^{\circ} \mathrm{C}$ に加熱した構造用炭素鋼 (S45C)の表面に $\mathrm{Al}$ 粒子を投射し，その後 30 秒間同じ温度 を維持した後に冷却した試験片の断面を光学顕微鏡により観 察した結果である。同図から，表面近傍には基材とは様相の 異なる層が形成されていることがわかる。この層の化合物同 定をXRDにより行ったところ，この層が金属間化合物 $\left(\mathrm{Fe}_{2} \mathrm{Al}_{5}\right)$ であることが明らかとなっている。ここに含まれる Fe 成分は基材に由来するものであり，基材成分を積極的に 利用する点はこの手法の特徵のひとつと言える。図 6 は, こ の層のビッカース硬さ測定を行った結果である。同図から, 厚さ $100 \mu \mathrm{m}$ 程度の領域で高硬さとなっていることがわかる。 なお，写真の最表面は，処理の最後に不可避的に形成された $\mathrm{A} 1$ の溶着層であり，実用化する際には除去するか，もしく はこのような層が形成されないように処理条件を工夫する必 要がある。なお, 䨌囲気ガスとしてはアルゴンなどの不活性 ガスを用いることが一般的であるが，窒素ガスを用いること により, チタンの超短時間窒化が可能なことも, 新しい事実

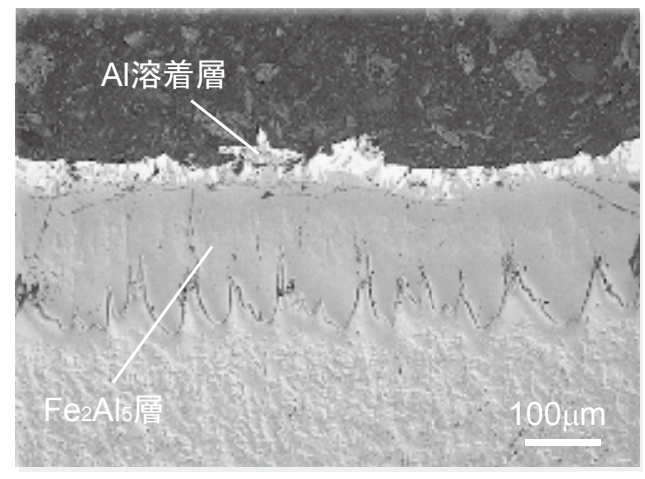

図 5 AIH-FPP により形成された金属間化合物層

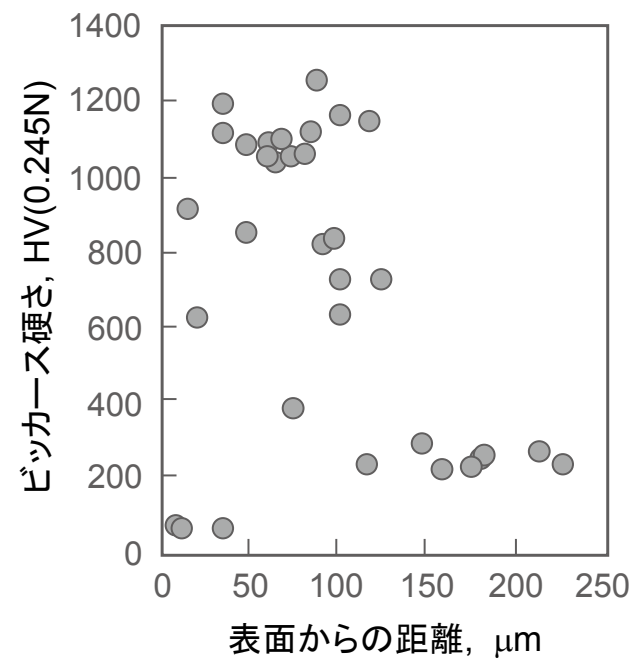

図 $6 \mathrm{Fe}_{2} \mathrm{Al}_{5}$ 層のビッカース硬さ

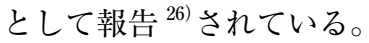

投射粒子に工夫を加えて，構造用鋼表面の高温酸化性に優 れる金属間化合物層を形成しようとする試みも行われている。 具体的には $\mathrm{Ti}$ 粒子と $\mathrm{Al}$ 粒子をメカニカルミリングにより複 合化して，それをAIH-FPPにより被処理面に投射すること により金属間化合物層の創成が可能になることが報告 ${ }^{30), 31)}$ されている。

図 7 は，表 1 に示す条件のもとで，Ti 粒子と $\mathrm{Al}$ 粒子を $\mathrm{Mol}$ 比で 1：3の割合で混練した粒子(ここでは Ti/Al MM 粒 子と呼ぶ）をSEMにより観察した結果と同じ個所を EDXに より分析した結果である。メカニカルミリングの条件に依存 して創られる粒子の性状は異なるが，同図から，両成分が満 遍なく分布されていることがわかる。この粒子を，表 2 に示 す条件で構造用鋼表面に投射した試験片を準備し，その断面 の表面近傍を SEM 観察およびEDX 分析した結果が図 8 で ある。同図から, $\mathrm{Fe}, \mathrm{Ti}$ および $\mathrm{Al}$ を含む $300 \mu \mathrm{m}$ 程の極め て厚い層が形成されていることがわかる。なお，この層を XRD により分析した結果, $\mathrm{TiAl}$ や $\mathrm{TiAl}_{3}$ に加えて, Fe を含 む 3 元系の金属間化合物も形成されていることが明らかと なっている。

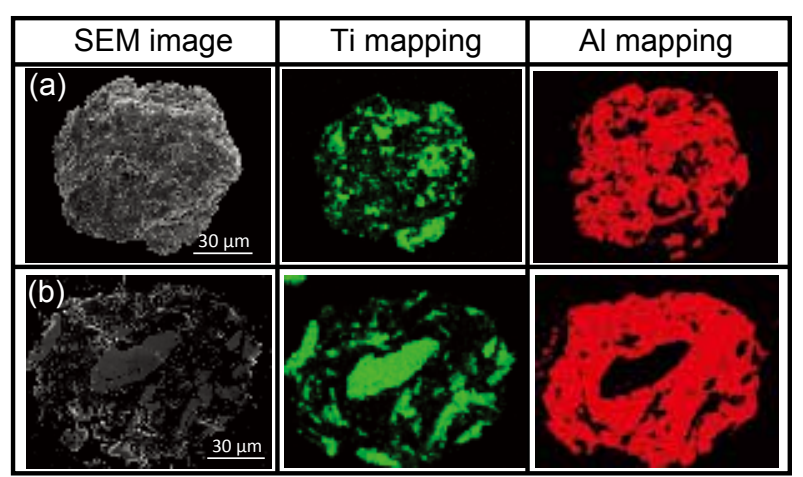

図 7 メカニカルミリングにより作製した粒子の様相 (a) 外観, (b) 断面

表 1 メカニカルミリング処理の条件

\begin{tabular}{c|c}
\hline Powders mixture device & P-6 \\
\hline Total powder amount & $20 \mathrm{~g}$ \\
\hline Ti to Al ratio (Ti:Al), at $\%$ & $1: 3$ \\
\hline Ball to powder ratio (ball:powder), wt $\%$ & $10: 1$ \\
\hline Isopropanol, wt $\%$ & $1 \%$ \\
\hline Milling time of 1cycle, min & 5 \\
\hline Pausing time of 1 cycle, min & 15 \\
\hline Cycle numbers & 72 \\
\hline Total milling time & $6 \mathrm{~h}$ \\
\hline Rotation speed & $360 \mathrm{rpm}$ \\
\hline Revolution speed & $200 \mathrm{rpm}$ \\
\hline Atmosphere & $\mathrm{Ar}$
\end{tabular}

表 2 AIH-FPP 処理条件

\begin{tabular}{c|c}
\hline Atmosphere & $\mathrm{Ar}$ \\
\hline Shot paticles & $\mathrm{Ti} / \mathrm{A} 1 \mathrm{MM}$ particles, \\
\hline Nozzle distance & $100 \mathrm{~mm}$ \\
\hline Treatment temperature & $1000{ }^{\circ} \mathrm{C}$ \\
\hline Peening pressure & $0.5 \mathrm{MPa}$ \\
\hline Particle supply rate & $0.1 \mathrm{~g} / \mathrm{s}$ \\
\hline Peening time & $10 \mathrm{~s}$ \\
\hline Heating time & $60 \mathrm{~s}$ \\
\hline
\end{tabular}




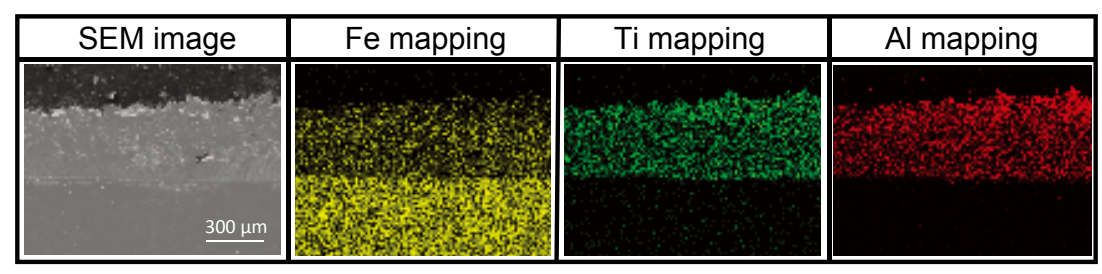

図 $8 \mathrm{Ti}: \mathrm{Al}=1: 3 \mathrm{MM}$ 粒子を用いた処理試験片の断面分析

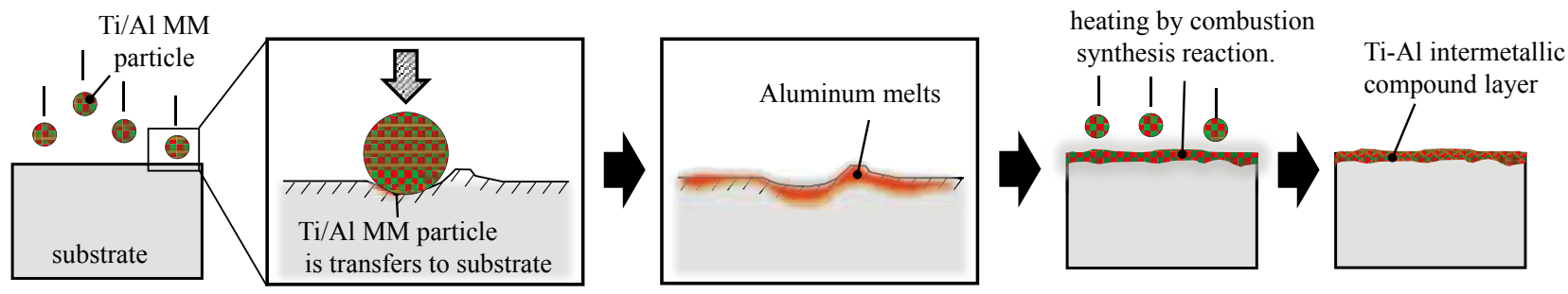

図 9 AIH-FPP による Ti-Al 金属間化合物層創成メカニズム

AIH-FPP 処理により, 投射する粒子の融点より低い温度で の処理にも関わらず，混入した低融点の $\mathrm{Al}$ 粒子がフラック スとして作用し, その結果, Ti の融点が局所的に低下する ことや，両成分の燃焼合成反応により，投射部位が局所的に 高温になることなどが原因と考えられている(図 9)。

\section{5.おわりに}

本報では，タイトルにある通り，微粒子ピーニングによる 加工熱処理と金属間化合物層の創成に着目をして最近の研究 動向を述べた。微粒子ピーニングを利用した表面改質は冒頭 に述べた以外にも, 数多く存在する。 $1+1$ が 3 にも 4 にも なるようなハイブリッド表面改質にもこの微粒子ピーニング が利用されている。今後, これらの処理を幅広く実用化する ためには，処理システムのインライン化なども考慮にいれた 研究開発が必要と考えている。

(Received December 8, 2015)

\section{文献}

1 ）加賀谷忠治; 表面技術, 52, 169 (2001).

2 ) 宮坂四志男; 精密工学会誌, 72,1075 (2006).

3 ) 高木眞一, 熊谷正夫; 精密工学会, 72, 1079 (2006).

4 ) N.R. Tao, M.L. Sui, J. Lu, K. Lu ; NanoStructured Materials, 11, 433 (1999).

5 ) S. Takaki ; Materials Science Forum, 426-432, 215 (2003).

6 ) 高木眞一, 熊谷正夫, 伊藤裕子, 小沼誠司, 下平英二 ; 鉄と鋼, 92 , 318 (2006)

7 ) M. Umemoto ; Materials Transactions, 44, 1900 (2003).

8 ) M. Umemoto, Y. Todaka, K. Tsuchiya ; Materials Transactions, 44, 1488 (2003).

9 ）戸高義一, 梅本 実, 渡辺幸則, 土谷浩一; 日本金属学会誌, 67 , 690 (2003)

10) Y. Todaka, M. Umemoto, Y. Watanabe, K. Tsuchiya ; Materials Science Forum, 503-504, 669 (2006).
11) S. Kikuchi, J. Komotori ; Materials Transactions, 56, 556 (2015).

12）小茂鳥潤 ; 精密工学会誌, 72, 1083 (2006).

13）長井 篤, 宮田昌悟, 斉藤万里雄, 小茂鳥潤, 小尾晋之介, 難波洋 司,小山尹誉; 日本機械学会論文集A編, 77, 544 (2011).

14）笹子敦司, 菊池将一, 亀山雄高, 小茂鳥潤, 媣沢剣吾, 三阪佳孝, 川 䇏一博; 日本金属学会誌, 72, 347 (2008).

15）伊藤達也, 菊池将一, 亀山雄高, 小茂鳥潤, 深沢剣吾, 三阪佳孝, 川 訔一博; 日本金属学会誌, 74, 533 (2010).

16）福岡隆弘, 菊池将一, 小茂鳥潤, 深沢剣吾, 三阪佳孝, 川龒一博; 日 本金属学会誌, 75, 372 (2011).

17) S. Kikuchi, A. Sasago, J. Komotori ; Journal of Materials Processing Technology, 209, 6156 (2009)

18）原田 翼, 菊池将一, 小茂鳥潤, 深沢剣吾, 三阪佳孝, 川菩一博; 材 料, 60, 1091 (2011).

19) T. Fukuoka, Y. Ujiie, J. Komotori, K. Fukazawa, Y. Misaka, K. Kawasaki ; Procedia Engineering, 10, 1503 (2011).

20）天野有規, 天野悟志, 福岡隆弘, 小茂鳥潤 ; 材料, 61, 273 (2012).

21）福岡隆弘, 菊池将一, 小茂鳥潤, 深沢剣吾, 三阪佳孝, 川罢一博; 日 本金属学会誌, 76, $422(2012)$.

22）亀山雄高, 天野有規, 小茂鳥潤, 深沢剣吾, 三阪佳孝, 川萨一博; 日 本金属学会誌, 77,7 (2013).

23) S. Kikuchi, T. Fukuoka, T. Sasaki, J. Komotori, K. Fukazawa, Y. Misaka, K. Kawasaki ; Materials Transactions, 54, 344 (2013).

24）亀山雄高, 竹嶋隼人, 小茂鳥潤, 村澤功基; 日本金属学会誌, 79, 452 (2015).

25）太田俊平, 村井一恵, 小茂鳥潤, 深沢剣吾, 三阪佳孝, 川䇏一博; 日 本金属学会誌, 79, 491 (2015)

26）太田俊平, 菊池将一, 曙 紘之, 大宮正毅, 小茂鳥潤, 深沢剣吾, 三 阪佳孝, 川訔一博; 砥粒加工学会誌, 59,643 (2015).

27）園田哲也, 桑嶋孝幸, 中村 満, 齋藤 貴, 安岡淳一; 溶接学会論 文集, 28, 305 (2010).

28）園田哲也, 桑嶋孝幸, 中村 満, 齋藤 貴, 伊藤 乃; 溶接学会論 文集, 28,376 (2010).

29）榊 和彦; 表面技術, 59, 490 (2008).

30）齋藤周也, 鈴木広野, 小茂鳥潤, 深沢剣吾, 三阪佳孝, 川嵩一博 ; 2015年春期講演大会講演概要集, P13（日本金属学会, 2015).

31）鈴木広野, 齋藤周也, 小茂鳥潤, 深沢剣吾, 三阪佳孝, 川菩一博; 2015年春期講演大会講演概要集, 339 （日本金属学会, 2015）. 